\title{
The Management Strategy of Marketing Mix of Pineapple Chips in Kampar District, Riau Province, Indonesia: A Structural Model Approach
}

\author{
Roza Yulida \\ Department of Agribusiness, Faculty of Agriculture \\ Riau University, Pekanbaru, Riau, Indonesia \\ rozayulida@lecturer.unri.ac.id \\ Jum'atri Yusri \\ Department of Agribusiness, Faculty of Agriculture \\ Riau University, Pekanbaru, Riau, Indonesia \\ jum_yusri@gmail.com \\ Novia Dewi \\ Department of Agribusiness, Faculty of Agriculture \\ Riau University, Pekanbaru, Riau, Indonesia \\ dewinovia642@gmail.com \\ Yulia Andriani \\ Department of Agribusiness, Faculty of Agriculture \\ Riau University, Pekanbaru, Riau, Indonesia \\ yulia.andriani@lecturer.unri.ac.id
}

(Received: Oct 26, 2016; Reviewed: Oct 31, 2016; Accepted: May 17, 2017)

\section{DOI: http://dx.doi.org/10.20956/ijas.v5i1.1167}

\begin{abstract}
The Management of marketing mix in agro-industry business of pineapple chips need to increase the volume of sales and customer loyalty. This research aims to (1) analyze the variable/ attribute lever in the management of the marketing mix of pineapple chips, and (2) formulating marketing strategy of pineapple chips. This research used survey method. The Selection of respondents in this research is intentional (purposive sampling). The determination of respondents based on the expertise and their role in policy-making related to the agroindustry of pineapple chips. Data analysis used prospective analysis and Analytic Hierarchy Process/AHP. The Results of analysis showed that the determinants of the management of the marketing mix of pineapple chips consists; the dimensions of the product, price, promotion, and distribution. Attributes that are included in the driving variables consists of; products that always available, distribution in craftsmen kiosks, available in souvenir outlets, available anywhere, and promotions through packaging. The attributes are located in quadrant I, which have strong influence and dependence among low attributes. The direction of development of marketing policy of pineapple chips, alternatives include; Alternative I is the institutional strengthening of marketing and alternative II, is the development of the marketing mix.
\end{abstract}

Keywords: Determinant; management of the marketing mix; marketing strategy 


\section{Introduction}

The twenty-first century processes of globalization result in a significant change in all business environments. Companies have to change their usual practices. Nowadays, trading companies that seek to meet the needs of customers cannot rely on any previous job application techniques. Customers are becoming choosier; they are not sufficient for traditional marketing solutions. Users are encouraged to exchange a trading sector company, whereas its management has to adapt and to provide an updated marketing mix. Companies are facing high competition, so that to run a successful business activity in the trade sector, need to do the following: to expand the range of services, sell quality goods, to pay in order to satisfy the desires of buyers, and to reduce costs. It is also important to align and effectively use marketing mix elements and their actions in order to achieve effectiveness. Effective marketing mix management enables marketers to create a combination of elements that will enable wisely manage the company's budget in order to achieve the desired objectives (Isoralte, 2016).

Today, a growing companies is an agricultural based business. Areas tht hve good agricultural potential, began to be developed toward the industry. Kampar Regency is a potential area in the development of various agricultural commodities in Indonesia. One of them with pineapple commodity production reached 12,750 tons from 13.25 million existing pineapple tree (BPS Kampar regency, 2014). Based on this potential will require processing business, that is agro-industry of pineapple chips in order to realize an effec- tive and efficient agribusiness. The growing number of pineapple chips enterprenur was followed by the increasing number of machine owned by the enterpreneur, ranging from 1-4 unit vacum frying machine for each enterpreneur. The average production cost of pineapple chips produced by 4 times production process scheme/ day are Rp.15.514.749 for 1 machine, Rp. 34.199.267 for 2 machine, and Rp. 62.515.120 for 3 machine. The average production cost of pineaplle chips, produced by 3 times production scheme/ day with 4 unit machine is Rp. 57.478.340. The efficiency levels ranging between 1,27 (the average efficiency of 1 unit machine) up to 1,78 (the average efficiency of 4 unit machine). While the value added obtained per unit machine is abour 9 million rupiah or $38.000 / \mathrm{kg}$. Some of the products $(60 \%)$ were marketed through broker or wholesaler, the others $(40 \%)$ were directly sold to the consument using their own brands (Rosnita, 2014).

The Production of pineapple chips are produced by fourteen agro-industries in Kualu Nenas village marketed on limited to fulfill the request from souvenir outlets so that network marketing is still limited by the uncertainty of a high enough price. The sustainability of Pineapple chips agro-industry is largely determined by production capacity, the ability to gain market share, and maintain the customer. Based on the previous description to Overcome the problems of pineapple producers it need a marketing mix that can improve productivity and quality.

In order to actualize an efficient and effective agribusiness, it needed a good marketing in order to increase the income of 
farmers and craftsmen of pineapple chips. An important feature of the agro-industry is the activity is not depending on the season, need a modern business management, business scale achievement of optimal and efficient, and able to create high value-added (Hasyim and Zakaria, 1995). The agroindustry of Pineapple chips must be able to market their goods or services that are produced to the consumer in order to survive and compete with other business. Kotler and Armstrong (2001) the product quality is a strategic weapon with the potential to beat your competitors. Only agro-industry with most excellent product quality will grow exponentially and the long-term, the company will be more successful than other companies. Quality and trust is a decisive determinant (factor) of Indonesian tuna competitiveness in the Japanese market (Hidayati, 2015).

The potential of Kuala Nenas village in terms of pineapple production should be able to make agro-industry of pineapple chips became icons of Riau and should be able to make sales to the country and outside the island. One of the reason is the promotion that done by craftsmen of pineapple chips in Kualu Nenas Village is not maximize yet. Maximum promotion certainly have an impact on sales volume. There are costumers who buy the product because of the low price, high quality, good quality, and easily to find information about a product, someone would be considered a close distance, the complete store, the arrangement of the items are interesting, satisfactory service as well as a spot of shopping favorable. The Agro-industry of Pineapple chips in kuala Nenas village locat- ed alongside highway, but the arrangement of stalls as well as the cleanliness of the store is still unnoticed. In connection with these problems, this research aims to analyze the attributes of lever in the marketing and formulate marketing mix management strategy of pineapple chips.

The marketing mix by 4P's is a conjuration and it can only be implemented by marketing managers. Marketing mix is a greatest strategy for attaining competitive advantage for any firm. The customer is king thus it is mandatory to employ excellent marketing mix by marketing manager is essential as these key elements will satisfy the customer need and demands. It isi highly necessary to plan and implement appropriate marketing mix of 4P's for competitive advantage. Marketing management is about placing the right product, at the right price, at the right place, at the right time. Singh (2012) describe the importance of relationship of various components of marketing mix for attaining competitive advantage in market. Marketing Mix comprises of Product marketing mix and Service marketing mix. Generally the Product marketing mix consists of product, price, place and promotion and it is generally used for marketing mix of tangible goods.

\section{Methods}

\subsection{Research Site}

This research held in Kualu Nenas village, Kampar regency Riau Province Indonesian from December 2015 until March 2016. The Location research was done intentionally (purposive sampling) with consideration there are centers of agro-processing activities pineapple chips that have prospects for 
developing and maintaining local resources as an asset of regional wealth.

\subsection{Sampling and Data Method}

The method used in this research is survey method that do direct research in the field by interviewing respondents. The Selection of respondents in this research was done intentionally (purposive sampling), which is related to the agro-industry stakeholders of pineapple chips. The etermination of the respondents based on expertise and its role in policy-making related to the agro-industrial pineapple chips. The number of respondents were 9 people.

Data used in the research include primary and secondary data. The primary data obtained by conducting in-depth interview to the respondents and using a structured questionnaire. While the secondary data obtained from relevant agencies and reference sources that support this research.

\section{Data Analysis}

\subsection{Analysis Prospective}

Prospective analysis is a method used to analyze the problem in the expert system that can incorporate decision-makers in order to reconstitute some planning with different approaches (Bourgeois and Jesus, 2004). Prospective analysis aims to determine the position from the attributes of the lever so that it will be obtained the key attributes or determining factor (driving variables). Out put prospective analysis will be obtained four (4) quadrants are attributes lever position, as shown in Figure 1.

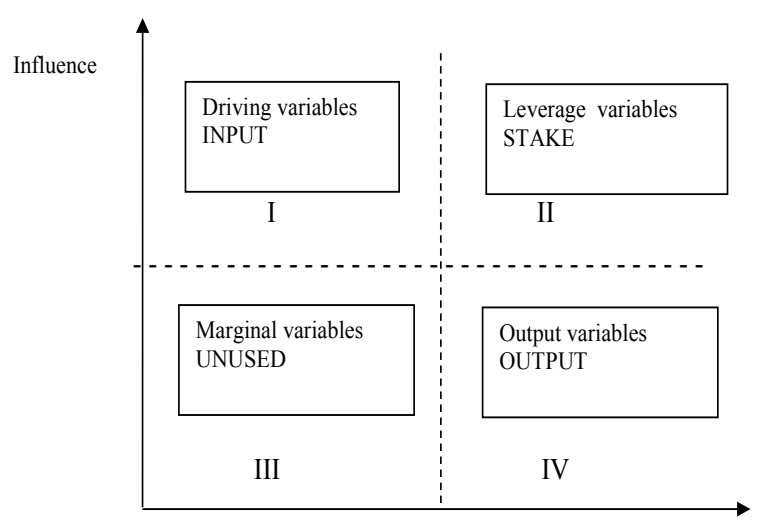

Figure 1. Importance level of the Factor

Information:

- Quadrant I: the input quadrant which is quadrant of the determinant variables (driving variables). This quadrant contains attributes that have a strong influence and dependence among low attributes.

- Quadrant II : the stake quadrant which is the quadrant of the link variable (leverage variables). This quadrant contains attributes that have a strong influence and dependence among attributes are also strong.

- Quadrant III: the quadrant output which is a quadrant of the dependent variable (output variables). This quadrant contains attributes that have a low impact and dependencies among these strong attributes.

- Quadrant IV: unused quadrant which is the quadrant of independent variable (marginal variables). This quadrant contains attributes that have a low impact and dependence among attributes are also low.

\subsection{Analysis AHP}

The data analysis using the Analytic Hierarchy Process (AHP) is a decision support models developed by Thomas L. Saaty. This model will describe a complex 
multi-factor problem into a hierarchy. According to Saaty (2008), the hierarchy is a representation of a complex problem in a multi-level structure where the first level is purpose followed level factors, criteria, sub-criteria, and so on down to the last level of alternative. Experts grading scale based criteria using pairwise comparisons. According to Marimin (2004), AHP has an advantage in explaining the decision-making process as depicted graphically so easily understood.

\section{Results And Discussion}

Marketing elements; product, price, place and promotion are used for marketing objectives. These instruments operate most efficiently when all the elements are combined and working together (Isoralte, 2016). The marketing mix concept also has two important benefits. First, it is an important manager's job is, in a large part, a matter of trading off the benefits of one's competitive strengths in the marketing mix against the benefits of other. The second benefit of the marketing mix is that it helps to reveal another dimension of the marketing manager's job (Chai Lee Goi, 2009).

\subsection{Attribute Lever in Management of Marketing Mix of pineapple chips}

Attributes lever in the marketing mix of pineapple chips, is the five product dimension attributes, the price of three attributes, the promotion of three attributes, and distribution of four attributes. The lever attributes give the highest influence to sustainability of marketing of pineapple chips. those Fifteen attribute levers further assessment of the level of influence between attributes, either directly or indirectly. This is done because there is a relation between each attribute in the management of the marketing mix of pineapple chips. The relation between these attributes can be either influence or dependence among attributes. The results of a prospective analysis is obtained as shown in Figure 2.

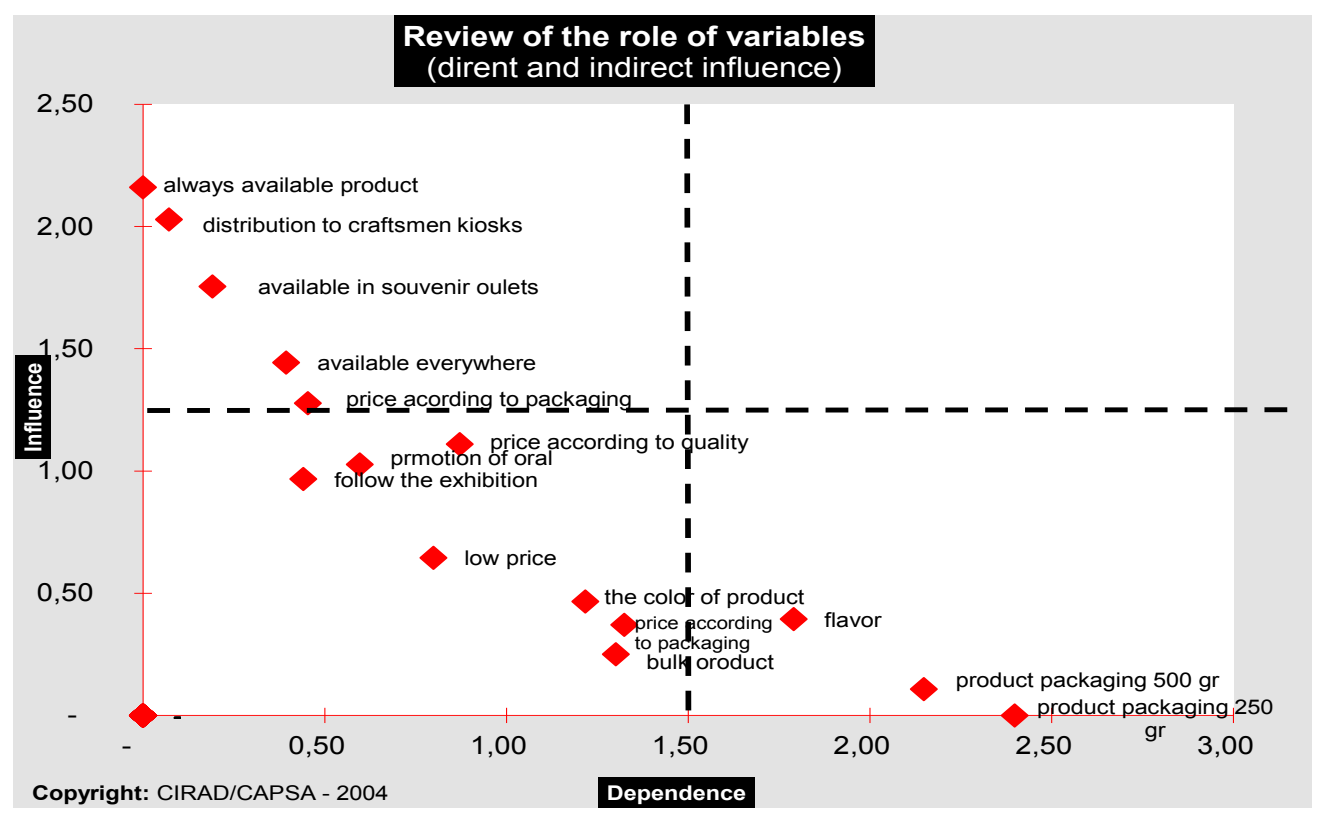

Source: Analysis Result, 2016.

Figure 2. Attribute lever in the management of the marketing mix of pineapple chips. 
Based on the results of a prospective analysis, as shown in Figure 2, shows that the type of distribution tend to gather in quadrants I and III quadrant. This type indicates that the system is stable because it shows a strong relation where the driving variable/deciding set variables strongly bonded (Bourgeois and Jesus, 2004).Based on the results of a prospective analysis, as shown in image 2, shows that the type of distribution tend to gather in quadrants I and III quadrant. This type indicates that the system is stable because it shows a strong relation where the driving variable/ deciding set variables strongly bonded (Bourgeois and Jesus, 2004). Attributes that are included in the driving variable consists of; products that always available, distribution in craftsmen kiosks, available in souvenir outlets, available anywhere, and promotions through packaging. The attributes are located in quadrant I, which is an attribute that has a strong influence and dependence among low attributes. This attribute is an attribute decider against the successful marketing of pineapple chips.

\subsection{Alternative Tutorial in Management of} Marketing Mix of pineapple chips

Marketing mix - certain actions and decision aimed at the company's goal and meeting the costumer needs. In these modern times, the company operates in a constantly changing environment. In order to successfully set up and remain profitable it is necessary to provide services that can meet the needs of customers. To this end, the marketing expert who are constantly monitoring the environment and its changes can properly re- spond and adapt to them. Businesses are very important for users, whose desires should be satisfied. Satisfaction is implemented in decisions and actions related to the $4 \mathrm{p}$ complex element. This complex is composed of the company's variable. The product - is a marketing element, covering decisions and actions related to the sale of property development or change. Price - element of the marketing mix, covering decisions and actions related to pricing and variation. Distribution - this element of the marketing mix, which includes decisions and actions related to the movement of goods from producer to consumer. Sponsorship - actions and decisions in order to create a smoother relationship between the supplier and the end user. (Margarita Isoralte, 2016).

The hierarchical structure of marketing management of pineapple chips, consist of; purpose (management of the marketing mix of pineapple chips), criteria (product, price, promotion, distribution), sub-criteria (product packaging 250 gr, product packaging 500 $\mathrm{g}$, bulk products, flavor, color of products, low prices, price according to the packaging, price according to the quality, promotion of oral, following the exhibition, promotion through packaging, distribution is everywhere; in souvenirs outlets; in craftsmen kiosks; and the product is always available) and alternative (institutional strengthening marketing and development of the marketing mix). More detailed in Figure 3.

Based on the analysis results with CD Plus AHP software, obtained that alternative $I$ is the institutional strengthening of marketing of pineapple chips with value of 0.667 or about $66.70 \%$, and alternative II is 


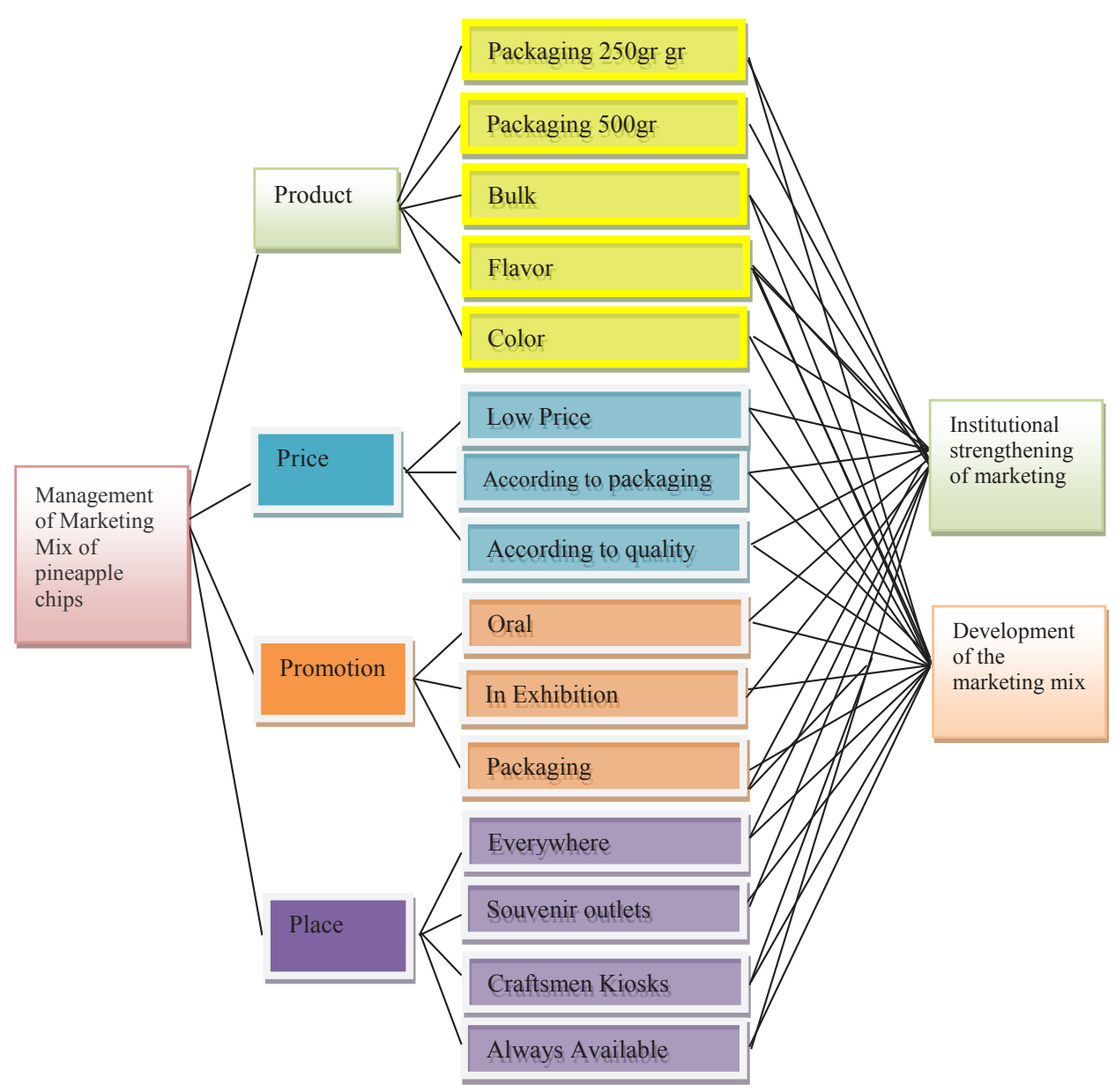

Source: Research planning, 2016

Figure 3. The hierarchical structure of marketing of pineapple chips

the management of product marketing mix of pineapple chips with value of 0.333 or about $33.30 \%$ (Figure 4 ). The value of the AHP analysis acceptable considering the consistency ratio value is 0.0 or less than 0.1 (10\%). According to Saaty (2008), comparison matrix can be accepted if the value of the consistency ratio $<0.1$.Pineapple chips institutional strengthening marketing with prioritizing promotion through packaging attributes. Shimp (2000) said that the promotional activities consist of all marketing activities that try the action of fast purchase of a product or the purchase in a short time. Covering various methods to communicate the advantages, benefits of certain products to potential and actual customers. However, for packing boxes on a few craftsmen still make the consumer a bit confused by the trademark because on the packing box there are too much color so its difficult to find a brand name such as agro industry Prima Tani, Berkat Bersama, Sakinah I and Sakinah II.Furthermore, the completeness of other packaging attributes such as inclusion of expired products and composition of the product needs to be added. Improvements in institutional marketing that is needed is the need to negotiate a craftsman especially with wholesalers who had been buying large volumes in the form of bulk pineapple chips but packaging use their brands.Brand whis 
is formed will influence the product branding and customer loyalty, which in turn have an impact on the volume of product sales. If the condition is not corrected then the craftsmen position remains as price takers. Cooperative marketing can be a great opportunity or a headache, Natural Sources (2016). The cooperative members, however, were still constrained by the lack of a reliable market source and the lack of access to credit (Yeboah, 2005).

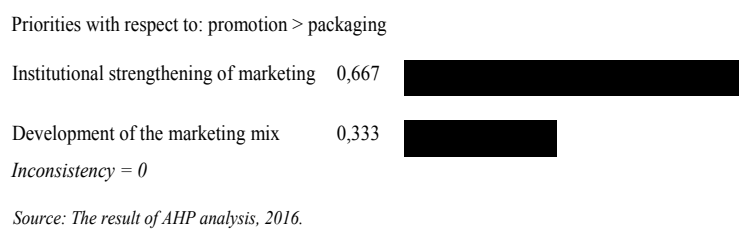

Figure 4. Alternative direction of marketing development of pineapple chips

\section{Conclusion}

Determinant attribute management of marketing mix of pineapple chips include: the dimensions of the product, price, promotion, and distribution. Attributes that are included in the decision variables (driving variables) consists of; products that always available distribution in kiosks craftsmen, is available in souvenir outlets, available anywhere, and promotions through packaging. The attributes are located in quadrant I, which is an attribute that has a strong influence and dependence among low attributes. The direction of marketing policy development of pineapple chips, alternatives include; Alternative I is the institutional strengthening of marketing $(66.70 \%)$, and alternative II is the development of the marketing mix (33.30\%). The need to improve marketing institution of pineapple chips in an effort to reduce dependence craftsmen against wholesalers who buy in bulk and use their own packaging and trademarks, it is adverse craftsmen. In relation with the need to strengthen the institutional marketing of craftsmen with one brand and joined in a container as a center of souvenirs.

\section{References}

Badan Pusat Statistik (BPS) Kabupaten Kampar, (2014). Kabupaten Kampar Dalam Angka 2014. Bangkinang

Bourgeois, R and Jesus,F. (2004). Participatory prospective analysis. Exploring and anticipating challanges with stakeholders. Center for Alleviation of Poverty through Secondary Crops Development in Asia and the Pacific, Monograph,46,1-29.

Chai Lee Goi, (2009). A Review of Marketing Mix: 4P's Or More?. International Journal of Marketing Studies. Vol. 1 No. 1, May 2009. www.ccsnet.org/ journal.html: 2-15.

Hasyim, $\mathrm{H}$ and W.A Zakaria. (1995). Pengembangan Agribisnis di Provinsi Lampung dalam Era Pasca GATT Jurnal Sosial Ekonomika. Vol 1 No 1 Juni 1995. Fakultas Pertanian.Universitas Lampung. Bandar Lampung.

Hidayati Sri, Dwidjoono HD, Masyhuri, Kamiso HN. (2015). Analysis of Determinant Indonesian Tuna Fish Competitiveness in Japanese Market. International Journal of Agriculture System (IJAS) Vol 3 Issue 2, December 2015:169-178.

Isoralte Margarita, (2016). Marketing Mix Theoretical Aspect, International Journal of Research - Granthaalayah A 
knowledge Repository. Isoralte*, Vol. 4 (Iss.6): June, 2016, 25-37.

Kotler, P and Armstrong, G. (2001). PrinsipPrinsip Pemasaran, Jilid 1. Jakarta: Erlangga.

Marimin. (2004). Teknik dan aplikasi pengambilan keputusan kriteria majemuk. Jakarta: Gramedia Widia sarana Indonesia.

Natural Resources. (2016). Farming Alternative: A guide to Evaluating the Feasibility of New Farm-Based Enterprises. 413(607)255-7654.

Saaty, T.L. (2008). Decision making with the analytichierarchyprocess:Int.J.Servic- es, 1(1),83-98.

Singh Meera, (2012). Marketing Mix of 4P's for Competitive Adventage. IOSR Journal of Business and Management (IOSRJBM). ISSN: 2278-487X Volume 3 Issue 6 (Sept - Oct, 2012) PP $40-45$. www.iosrjournals.org: 40-45.

Shimp, T, A. (2000). Periklanan Promosi. Jakarta: Penerbit Erlangga.

Yeboah, G. (2005). The Farmapine Model: A Cooperative Marketing Strategy and a Market-Based Development Approach in Sub-Saharan Africa. A publication of The American Agricultural Economics Association. 